\title{
APLIKASI SIMPLE HAND WASHING STATION TERHADAP PERILAKU CUCI TANGAN DALAM PENCEGAHAN PENULARAN COVID-19 DI DESA DILEM KECAMATAN KEPANJEN
}

\author{
Application Of Simple Hand Washing Station On Handwashing Behavior In Covid-19 \\ Transmission Prevention In Dilem Village, Kepanjen Distri
}

\author{
Yuyud Wahyudi I* \\ Lilis Sulistiya Nengrum² \\ Icca Presilia Anggreyanti ${ }^{3}$ \\ *ISTIKes Widya Cipta Husada, Malang, \\ Indonesia \\ 2STIKes Widya Cipta Husada, Malang, \\ Indonesia \\ 3STIKes Widya Cipta Husada, Malang, \\ Indonesia \\ *email: lilissulistiya0 I@gmail.com
}

\section{Kata Kunci:}

Simple Handwashing Station

Perilaku Cuci Tangan

Pencegahan

COVID-19

\section{Keywords:}

Simple Handwashing Station

Behavio

Hand Washing

Prevention

COVID-19

\begin{abstract}
Abstrak
Coronavirus Disease 2019 (COVID-19) merupakan pandemi sekaligus ancaman global dimana virus ini telah menyebabkan banyak kasus kematian terkait setiap harinya di berbagai negara, salah satunya Indonesia. Simple Handwashing Station (SHS) merupakan salah satu upaya pencegahan yang dapat membangun perilaku cuci tangan yang tepat. Berdasarkan hasil penelitian dilakukan dalam bulan april di beberapa titik strategis di Desa Dilem, Kecamatan Kepanjen, Kabupaten Malang Jawa Timur. Penelitian ini menggunakan desain penelitian Quasy experimental dengan pendekatan One Group Pre Post test design dengan sampel warga Desa Dilem tepatnya RT 5 dan 6 RW I Lemah Dhuwur. Teknik analisis menggunakan uji Paired Sample T Test dengan hasil yang menunjukkan bahwa terdapat pengaruh aplikasi simple handwashing station terhadap perilaku cuci tangan yang tepat pada warga Desa Dilem dengan nilai $P$ value $<0,05$, berdasarkan hasil tersebut dapat disimpulkan bahwa terdapat efektivitas aplikasi simple hand washing station terhadap perilaku cuci tangan dalam pencegahan penularan COVID-19 di Desa Dilem Kecamatan Kepanjen, dengan adanya hasil ini diharapkan dapat menambah simple handwashing station dibeberapa titik strategis lainnya di Desa Dilem dalam pencegahan COVID-19.
\end{abstract}

\section{Abstract}

Corona virus Disease 2019 (COVID-19) is a pandemic which is now a global threat where this virus causes many people to die every day in various countries, one of which is Indonesia, this disease is caused by SARS-CoV-2. The many impacts caused by COVID-19 make Simple Handwashing Station (SHS) as one of the prevention efforts that can build proper hand washing behavior. Based on the results of research conducted from 13-18 April 2020 which is divided into 4 strategic points in Dilem Village. This study uses a Quasy experimental research design with a One Group Pre Post test design approach with a sample of residents of Dilem Village precisely RT 5 and 6 RW I Lemah Dhuwur. The analysis technique uses Paired Sample T Test with the results that show that there is an influence of the application of simple handwashing station on the proper hand washing behavior of the residents of Dilem Village with a $P$ value $<0.05$, based on these results it can be concluded that there is an effectiveness of the application of simple hand washing station for hand washing behavior in preventing COVID-19 transmission in Dilem Village Kepanjen District, with this result it is expected to be able to add a simple handwashing station in several other strategic points in Dilem Village in COVID-19 prevention.
\end{abstract}

\section{PENDAHULUAN}

\section{Organisasi Kesehatan Dunia (WHO)}

menyatakan bahwa Coronavirus Disease 2019 (COVID-

19) merupakan pandemi sekaligus ancaman global, dimana virus mematikan ini dapat menyebabkan berbagai gejala seperti pneumonia, demam, kesulitan bernapas, dan infeksi paru-paru. (Adhikari et al., 2020). Di Indonesia terhitung sampai tanggal 7 April 2020, telah didapatkan kasus COVID-19 sebanyak I.2I4.466 
kasus yang telah dikonfirmasi dan didapatkan dan

67.7677 kasus kematian (BNPB, 2020). Untuk menekan angka penyebaran COVID-19, Pemerintah Republik Indonesia telah melakukan konsolidasi multisektor pemerintah serta membentuk Gugus Tugas Percepatan Penanganan COVID-19. Secara legislative, upaya pemerintah dalam mengendalikan pandemi COVID-19 di Indonesia adalah dengan mengeluarkan PP No.2I Tahun 2020 tentang pembatasan sosial berskala besar dalam rangka percepatan penanganan Corona Virus Disease 2019 (COVID-19) (PERPRES, 2020) serta diikuti oleh peratuan menteri pada masing - masing bidang.

Namun demikian, kasus pasien baru positif COVID-19 terus menunjukkan peningkatan signifikan dari hari kehari. Per tanggal 7 April 2020, telah di dapatkan kasus COVID-19 sebanyak 2.738 kasus penderita dalam perawatan sebanyak 2.313 kasus, sementara sembuh hanya 204 orang, sedangkan yang telah meninggal sebanyak 221 orang (BNPB, 2020).

Dalam penanganan penularan COVID-19, perilaku cuci tangan yang baik dan benar memiliki peran yang sangat vital. Lebih lanjut, WHO menekankan bahwa cuci tangan yang baik dan benar merupakan protokol pertama dalam Basic Protective Measure dalam pencegahan penularan COVID-19 (WHO, 2020). Cuci tangan yang dimaksud adalah cuci tangan secara teratur serta bersih sabun dan air. Hal tersebut dilakukan karena mencuci tangan dapat membunuh virus yang ada di tangan (WHO, 2020; Dahlan, 2013). Kendati demikian, data riskesdas Kemenkes RI (2018) menyebutkan bahwa kurang dari separuh penduduk Indonesia mampu melakukan cuci tangan secara baik dan benar, tepatnya pada angka 49,8\%. Hal ini tentu dapat menunjang masivnya penyebaran virus COVID19 di Indonesia jika tidak ada upaya yang menyeluruh untuk memberikan pendidikan perilaku cuci tangan yang benar kepada masyarakat.

Upaya yang ada dan sudah banyak dilakukan oleh pemerintah adalah masih berupa himbauan pemerintah kepada masyarakat untuk selalu aktif cuci tangan dengan menggunakan sabun juga sudah banyak dilakukan, pemerintah juga sudah banyak melakukan sampel pemasangan tempat cuci tangan portable diberbagai titik keramaian seperti pasar dan tempat perbelanjaan lain (Kompas, 2020).

Penyediaan alat SHS sering kali dikaitkan dengan adopsi teknologi yang modern, sehingga pemenuhan alat cuci tangan yang harus tersedia di masyarakat memiliki tingkat ekslusifitas.

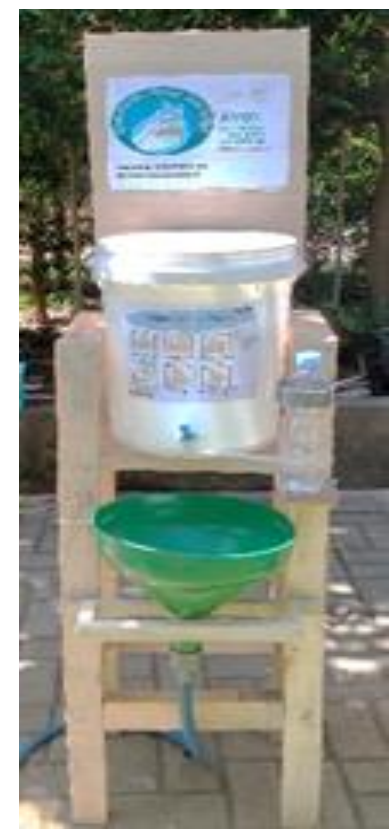

Gambar I. Simple Handwashing Station.

Biswas, D. et al. (20I7) telah melakukan uji coba yakni dengan membuat SHS, terlebih lagi alat cuci tangan tersebut dapat dibuat oleh siapa saja. Dalam penelitian tersebut mampu menunjukan hasil yang cukup signifikan dalam membentuk perilaku masyarakat terhadap kebiasaan cuci tangan yang baik di dua wilayah desa di daerah Dinajpur, Bangladesh utara. Selanjutnya Biswas, D. et al. (2017) mengemukakan maraknya kejadian diare pada balita di daerah Dinajpur, Bangladesh utara disebabkan oleh akses dan ketidaktahuan merupakan dasar dari perilaku ibu untuk tidak mencuci tangan sebelum memberikan makanan pada anaknya, maka dari itu dibuatlah SHS.

Aplikasi simple handwashing station didapatkan hasil bahwa SHS adalah cara yang efektif untuk membangun perilaku cuci tangan yang tepat dan dapat mengembangkan kreatifitas maupun inovasi masyarakat untuk mengembangankan cara pembuatan SHS sesuai 
kemampuan individu maupun masyarakat setempat (Biswas, D. et al., 2017).

Seiring dengan pandemic Covid -19 di dunia dan khususnya Indonesia, peneliti tertarik untuk melakukan penelitian tentang implementasi Aplikasi SHS terhadap perilaku cuci tangan dalam pencegahan penularan COVID-19 di Desa Dilem Kecamatan Kepanjen, Kabupaten Malang, Jawa Timur. Adapun penelitian ini ditujukan untuk melihat bagaimana pengaruh SHS terhadap perilaku cuci tangan masyarakat khususnya dalam pandemi Covid-19.

\section{METODE PENELITIAN}

Jenis Penelitian yang digunakan adalah Quasy experimental dengan pendekatan One Group Pre Post test design untuk menganalisis pengaruh aplikasi SHS terhadap perilaku cuci tangan dalam pencegahan penularan COVID-19 di Desa Dilem Kecamatan Kepanjen Kabupaten Malang, Jawa Timur.

\section{HASIL DAN PEMBAHASAN}

\section{HASIL}

\section{Analisis Univariat}

Tabel I. Data Umum Perilaku Cuci tangan sebelum intervensi SHS $(n=33)$

\begin{tabular}{clcc}
\hline No & $\begin{array}{c}\text { Perilaku Cuci } \\
\text { Tangan }\end{array}$ & Frekuensi & $\begin{array}{c}\text { Median } \\
\text { (min - } \\
\text { maks) }\end{array}$ \\
\hline I & $\begin{array}{l}\text { Mendekati nilai } \\
\text { min }\end{array}$ & 13 & $8(5-10)$ \\
\hline 2 & $\begin{array}{l}\text { Mendekati nilai } \\
\text { maks }\end{array}$ & 20 & 13 \\
\hline
\end{tabular}

Berdasarkan tabel I. diatas dapat diketahui bahwa nilai perilaku cuci tangan responden sebelum aplikasi SHS memiliki nilai median 8 , hal ini berarti nilai yang dimiliki responden adalah mendekati nilai minimum yang artiya diartikan bahwa perilaku cuci dengan 6 langkah adalah menunjukkan masih banyak perilaku yang kurang memperhatikan langkah cuci tangan yang baik dan benar.

Tabel 2. Data Umum Perilaku Cuci tangan Setelah intervensi SHS $(n=33)$

\begin{tabular}{cccc}
\hline No & $\begin{array}{c}\text { Perilaku Cuci } \\
\text { Tangan }\end{array}$ & Frekuensi & $\begin{array}{c}\text { Median } \\
\text { (min - } \\
\text { maks) }\end{array}$ \\
\hline $\mathbf{1}$ & $\begin{array}{c}\text { Mendekati nilai } \\
\text { min }\end{array}$ & 16 & $10(9-13)$ \\
\cline { 1 - 2 } & $\begin{array}{c}\text { Mendekati nilai } \\
\text { maks }\end{array}$ & 17 & \\
\hline & & & \\
\hline
\end{tabular}

Berdasarkan tabel 2. diatas dapat diketahui bahwa perilaku cuci tangan responden setelah implentasi aplikasi SHS memiliki nilai median sebesar 10 , bahwa perilaku cuci dengan 6 langkah menunjukkan ada perubahan yang cukup signifikan.

\section{Analisa Bivariat}

Aplikasi SHS terhadap perilaku cuci tangan dalam pencegahan penularan COVID- 19.

Tabel 3. Hasil Paired Sample T aplikasi SHS

\begin{tabular}{cccc}
\hline Kelompok & Sebelum & Sesudah & $\begin{array}{c}\mathbf{P} \\
\text { Value }\end{array}$ \\
\hline Baik & 13 & 16 & 0.000 \\
\hline Kurang & 20 & 17 & \\
\hline
\end{tabular}

Berdasarkan tabel 3. hasil mini riset tabel 2 yang dilakukan di Rt 5 dan Rt 6 Rw I Desa Dilem di dapatkan hasil bahwa terdapat keefektifitan aplikasi handwashing station terhadap perilaku cuci tangan warga RT 5 dan Rt 6 Rw I Desa Dilem Kabupaten Malang.

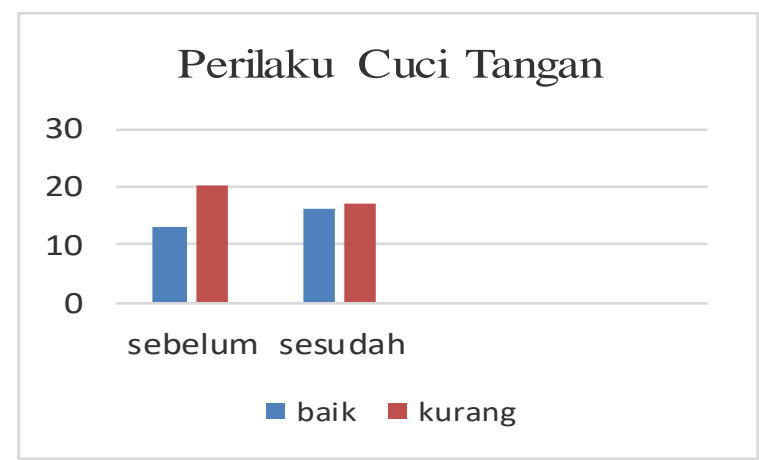

Gambar 2. Grafik Perilaku cuci tangan sebelum dan sesudah aplikasi SHS

Berdasarkan uji SPSS menggunakan uji Paired Sample $T$ Test di dapatkan hasil $0,000 \mathrm{P}=$ value $<0,05$ yang berarti terdapat nilai yang signifikan effektifitas aplikasi handwashing station terhadap perilaku cuci tangan warga RT 5 dan Rt 6 Rw I Desa Dilem Kabupaten Malang.

Hasil penelitian ini menunjukkan bahwa adanya keefektifan SHS terhadap perilaku cuci tangan 6 langkah dalam pencegahan penularan Covid-19 dengan nilai $p$-value sebesar 0,00 . Peningkatan skor perilaku cuci tangan setelah diberikan intervensi lebih tinggi dibandingkan dengan skor sebelum pemberian intervensi. Hampir serupa dengan penelitian di Bangladesh (Hulland, 20I3), penelitian menganalisa kemungkinan faktor faktor yang mempengaruhi penerimaan SHS di komunitas. Diantaranya adalah kemudahana alat dan kesederhanaan bahan yang dibutuhkan dalam 
pembuatan, faktor psikososial. seperti tingkat kepatuhan warga terhadap Perangkat Desa, tingkat kepadatan penduduk, tingkat sosial ekonomi. Selanjutnya, kemudahan akses juga akan mempengaruhi perilaku masyarakat dalam menerapkan cuci tangan 6 langkah (Biswas, D. et al., 2017). Hulland (2013) menambahkan bahwa penggunaan SHS juga dipengaruhi oleh faktor kebiasaan, khususnya ibu - ibu yang lebih memiliki penerimaan yang tinggi dikarenakan kepedulian mereka terdahap kebersihan dan pola hidup sehat anak anak. Keefektifan implementasi SHS dalam penelitian ini sejalan dengan temuan Biswas, D. et al. (2017) Dimana dalam penelitian tersebut didapatkan hasil bahwa SHS merupakan suatu cara yang efektif untuk membangun perilaku cuci tangan yang tepat.

Berdasarkan pernyataan diatas dapat disimpulkan bahwa terdapat keefektifan pengaplikasian Simple Hand Washing Station terhadap perilaku cuci tangan dalam pencegahan penularan Covid-19 di Desa Dilem Kecamatan Kepanjen. Namun dalam proses pengaplikasian Simple Hand Washing Station beberapa kendala. Wadah untuk sabun cair yang pertama kali dibuat menggunakan botol bekas, sedotan dan lem, terbukti tidak mampu bertahan lama. Selanjutnya ketika wadah botol bekas diganti dengan wadah yang lebih kuat, didapati hasil adanya pihak yang mengganti wadah baru yang lebih kuat dengan wadah sebelumnya (wadah botol bekas) tanpa adanya pemberitahuan kepada pihak peneliti.

\section{KESIMPULAN}

Berdasarkan riset yang telah dilakukan pada warga RT5 dan 6 di Desa Dilem dapat disimpulkan terdapat efektivitas aplikasi simple hand washing station terhadap perilaku cuci tangan dalam pencegahan penularan COVID-19 di Desa Dilem Kecamatan Kepanjen, dengan adanya hasil ini diharapkan dapat menambah simple handwashing station dibeberapa titik strategis lainnya di Desa Dilem dan Desa sekitar dalam pencegahan COVID-I9.

\section{DAFTAR PUSTAKA}

Adhikari, Sha Meng, Yu-ju Wu, Yu-Ping Mao, Rui-Xue Ye, Qing- Zhi Wang, Chang Sun, Sean Sylva, Scoott Rozelle, Hein Raat, Huan Zhou (2020) 'Epidemiology, Causes, Clinical Manifestation and Diagnosis, Prevention and Control of Coronavirus Disease ( COVID-19) During the Early Outbreak Period: a Scoping Review', BMC, 29(9), pp. I-12.

Azmi, F. (2020) 'Kasus Corona di Jatim Tembus 7.078, Ini Peta Persebarannya', Detik News, April. Available at: https://m.detik.com/news/berita- jawa-timur/d-4960599/kasus-corona-di-jatimtembus-7078-ini-peta-persebarannya.

Biswas Debashish, Fosiul, Sanghvi Tina, Roy Sumitro, Luby P. Stephen, E. Leanne. (2017) 'Provision versus promotion to develop a handwashing station: the effect on desired handwashing behavior'. BMC Public Health, (May). doi: I0.I I86/s I 2889-0I7-43 I66

BNPB (2020) Gugus Tugas Percepetan Penanganan COVID-19, Badan Nasional Penanggulangan Bencana. Available at: www.covid 19.go.id.

Dahlan, U. (2013) Buku Ajaran Ketrampilan Dasar Praktik Kebidanan. Malang: Inti Media.

Hulland, K. R. S, Leontsini Elli, U.Leanne, Afroz Aasma, Dutta C Notan, Nizame A Fosiul, Luby P Stephen, Ram Pavani, Winch Peter (20I3) 'Designing a handwashing station for infrastructurerestricted communities in Bangladesh using the integrated behavioural model for water, sanitation and hygiene interventions (IBM-WASH )', BMC Public Health. BMC Public Health, I3(I), p. I. doi: I0.1I86/|47|2458-13-877.

Kemendagri RI (2020) 'PP No.20 Tahun 2020 tentang Percepatan Penanganan Corona Virus Disease 2019 Di Lingkungan Pemerintah Daerah'.

KEMENDES (2020) 'Surat Edaran No. 8 Tahun 2020 tentang Desa Tanggap COVID-19 dan Penegasan Padat Karya Tunai Desa'.

Notoatmodjo, S. (20I3) Ilmu Kesehatan Masyarakat. Jakarta: Rineka Cipta.

PERPRES (2020) 'PP No. 2I Tahun 2020 Tentang Pembatasan Sosial Berskala Besar Dalam Rangka Percepatan Penanganan Corona Virus Disease 2019 (COVID-19)'. 